\title{
Factors Influencing the Usage of Broadband for the Youth and Adolescent in Bangladesh: A Cross-Sectional Study
}

\author{
Dewan Muhammad Nur -A Yazdani ${ }^{1}$, Tanvir Abir ${ }^{2}$, Kaniz Kakon ${ }^{3}$, Shaikh Sabbir Ahmed \\ Waliullah $^{4}$, Taha Husain ${ }^{5}$, Syeda Sabrina Akter Supty ${ }^{6}$ \\ ${ }^{1}$ Assistant Professor, College of Business Administration - CBA, International University of Business \\ Agriculture and Technology_IUBAT University, Dhaka-1230,Bangladesh;dewanm@iubat.edu \\ ${ }^{2}$ Associate Professor, College of Business Administration-CBA, International University of Business \\ Agriculture and Technology, Dhaka-1230, Bangladesh; tanvir.cba@iubat.edu \\ ${ }^{3}$ Assistant Professor, Department of Philosophy, College of Arts and Science - CAAS, International \\ University of Business Agriculture and Technology, Dhaka-1230, Bangladesh; kanizkakon@iubat.edu \\ ${ }^{4}$ Senior Lecturer, College of Business Administration-CBA, International University of Business \\ Agriculture and Technology, Dhaka-1230, Bangladesh; shaikh.waliullah@iubat.edu \\ ${ }^{5}$ Lecturer, Department of Gender and Development Studies, Begum Rokeya University, Rangpur. \\ Rangpur-5404, Bangladesh;ahmthusain@gmail.com \\ ${ }^{6}$ MPhil Research Fellow, Bangladesh University of Professionals. Dhaka, Bangladesh; \\ syedasupty@yahoo.com
}

\begin{tabular}{l} 
Article Info \\
\hline Article history: \\
Received: 05 September 2020 \\
Revised: 26 October 2020 \\
Accepted: 27 October 2020 \\
Keywords: \\
Broadband, \\
Loyal Customers, \\
Value Creation, \\
Satisfaction, \\
Barrier, \\
Cost, \\
Subscription \\
\\
JEL: O10, M15, M3, M42. \\
Paper Type : \\
Research Article \\
\hline Corresponding Author: \\
Dewan Muhammad Nur -A \\
Yazdani \\
Email: dewanm@iubat.edu
\end{tabular}

\section{Article Info}

Article history:

Revised: 26 October 2020

Accepted: 27 October 2020

Keywords

Value Creation,

Satisfaction

Barrier

Cost,

Subscription

Email. dewanm@iubat.edu

\begin{abstract}
Purpose: This study aimed at examining the adoption factors of broadband internet and exploring the factors which make difference between service providers.

Approach/Methodology/Design: Purposive sampling was employed to select the sample. To collect data from social media users, a close-ended Google Form questionnaire was administered through social networking sites and 376 responses were obtained. The data was analyzed using partial least squares structural equation modeling (PLS-SEM, 3.1). Model estimation was performed with $r 2, Q 2$, and the effect size f2 that describes the path effect from exogenous construct to endogenous construct.

Findings: This study revealed that the participants, despite having the barriers, were reasonably satisfied at different levels and it was a major motivation in the use of broadband. The use of broadband internet has not yet been improved substantially in Bangladesh due to the minimal internet speed, lack of decent standard of quality, and high maintenance cost. However, the study revealed that customer or user satisfaction created a huge positive impact on value creation. It was also statistically significant supporting the hypothesis of the study.

Practical Implications: The results of the study provide the broadband companies with an idea about broadband preference, assisting them in analyzing the variables closely to get more loyal customers.

Originality/value:

The study revealed that the degree of total frustration is below ten per cent, even though the severe challenge is considered very small. The study also showed that most of the participants were reasonably satisfied at different levels and it was a major motivation in the use of broadband.
\end{abstract}

\section{Introduction}

Since people are preoccupied as ever before with various online activities, Broadband Internet has rapidly become a function of daily life. Broadband services have become an important day- 
to-day need for the young and adolescent in Bangladesh for various education and IT-related freelancing work. Different types of people perform a wide range of online daily activities, including banking, shopping and social relations (Doster, 2013). Proliferation in tech-based marketing of various products including computers' network-enabled mobile, and laptop or palmtop added extra demand for broadband internet. Thus, it creates a huge bank of loyal customers who have bound to receive broadband internet service (Bhattacharjee et al., 2018). The broadband boom began in 2010 but broadband acceptance differs across nations irrespective of which social segments the customers belong to (Alderete, 2019). Certain considerations such as consumer age, class and social affiliations often play an important role in shaping broadband use (Birba \& Diagne, 2012; Touray et al., 2015).

Broadband internet providers, these days, are putting remarkable efforts to improve their services to win the competition with each other (Bashir \&Verma, 2017). Thus, trust or loyalty has been growing up between the service providers and the service receivers. However, there are still many challenges for this type of service. Assaf et al. (2017) revealed that the main obstacles associated with low internet adoption includes but not limited to the factors such as low economic status of the country. Furthermore, the infrastructure of the country is still developing, and the internet connection is still slow, expensive and not highly affordable by most people, especially the unemployed people (Hossain, 2004).

This study echoes the prevailing condition in Bangladesh in terms of demographic segmentation, internet infrastructure and affordability. Internet usage and subscription costs, affect consumers, particularly the adoption for the low-incoming people. The expense of broadband internet service often relies on the expense of facilities not specifically managed by mobile users, but on certain development-related costs (internet delivery towers, office and receiver wiring, locationdependent building construction, network connections) and maintenance costs. In this backdrop, the current study aimed to identify the factors, which influence and encourage the consumers to use the broadband internet as well as to find out various factors causing dissatisfaction among consumers.

\section{Literature Review}

\subsection{Broadband Connectivity}

Development of communication networks has a considerable influence on the advancement of global economies. It is also reflected in many nations through acceptance and usage together with the networks' rising performance (Koutroumpis, 2019). The emergence of highcommunication technology paves the way for the use of broadband internet as a true predictor increasing economic gains, creating general awareness, and improving people's lives (Choudrie \& Dwivedi, 2004). In particular, the latest developments in the broadband network allow endusers to provide high-speed connectivity to new networks and apps with realistic lifestyle and productivity benefits (Adams et al., 2017). It supports high bandwidth communication and higher data transmission speeds. It helps users to navigate emerging products, resources and necessary information quickly and continually for real life and thus helps to gain business efficiency (Owens et al., 2019). A study in Pakistan and the Kingdom of Saudi Arabia (Dwivedi et al., 2007) concluded that primary effect, enabling conditions and resource capital are critical 
factors of Broadband internet adaptation. On the other hand, usefulness, carrier efficiency, age, accommodation, has a significant impact on customer attitudes to broadband adoption. In developing countries such as India (Dwivedi \& Lal, 2007) Malaysia and the Kingdom of Saudi Arabia (Dwivedi et al., 2007), a variety of studies were carried out, but there were fewer research studies on the factors influencing the usage of broadband in Bangladesh. However, efficient broadband infrastructure is believed to help the advancement of Bangladesh's economy to a higher stage. An observational analysis in Bangladesh is important to understand the views and perceptions of consumers of broadband internet.

\subsection{Accessibility to Broadband}

Some studies emphasizing on the accessibility to broadband usage revealed that the socioeconomic structures of young generations, creativity within the organizations they worked and culture of the society they belong are greatly affected the usage of internet service (Gefen \&Straub, 2004; Venkatesh et al., 2007;Venkatesh et al., 2012; Meyoki \& Kavindah, 2019; Stanton, 2004). Accessibility to broadband internet varies considerably from the geographical area. Rural populations and individuals with low or no income are found as restricted access to broadband (Townsend et al., 2013; Copps, 2009; Assafet al., 2017; Grubesic, 2010; Horrigan \& Smith, 2008; Horrigan, 2010). Socio-economic factors such as employment, heterogeneous ethnicity and education affect the access to broadband internet (Strover, 2018). With the growing number of suppliers of Internet access, it would continue to reduce the expense of accessing broadband internet on a large scale in due course (Marino, 2017). Although it has been found that broadband internet connectivity is used extensively at affordable rates in many countries, the actual need for broadband usage has not greatly increased (Hair et al., 2011).

" $\mathrm{H}_{1}$ : Consumers ease of access opportunities acting as a barrier can influence broadband purchasing intention."

\subsection{Sought Benefits}

The customer interest to broadband internet includes various innovations of service providers, market deliberation and minimum price. Furthermore, the broadband benefit has been driven by the need of consumers at home, in particular as a shifting alternative from mobile operators driven internet service to broadband driven one (Doster, 2013). Many of the perceived benefits such as fast-speed, convenience, broadband consumption needs and other essential leisure choices, such as entertainment, have contributed to examine the broadband adoption (Bhattacharjee et al., 2018). It is observed that receiving internet services have become a critical aspect of a competitive global economy, growing physical and social alienation for the people (Birba \& Diagne, 2012). Seuwou et al. (2017) examined these concerns for potential internet connectivity that was commonly accessible and focused on different cost factors and infrastructural factors. While other technology-based hypotheses and well-established principles in the production and implementation of information systems have shown so much about the various adoption factors associated with broadband technology, more work is required to understand certain important factors that may affect the acceptance and usage of broadband technology, such as value creation with availability and reuse (Seuwou et al., 2017). Regarding 
the nature of network connectivity demand and the development of the user market utilizing broadband networks, a very little is understood so far (Rappoport et al., 2002).

" $\mathrm{H}_{2}$ : The benefits of broadband enterprises can positively influence the intention to avail broadband."

\subsection{Value Creation}

Some studies have examined why the majority of internet consumers have used broadband internet (Sianipar et al., 2018). Development of value relies on transparent functions that can be enhanced and shared by anyone without caring about immediate financial profits (Cedergren, 2003). The study of Kotler et al.(2019) indicated that companies could create strong consumer connections by creating a well-structured value chain. On the other hand, Buttle \& Maklan (2019) in their study further affirm this definition, explaining the customer relationship management as follows: "The function of customer relationship means the alignment of the company's internal processes with external factors to deliver input from selected consumers and produce income for the business". The most important thing is the history of potential clients embodied in the implementation of relationship management-based technology. Thus, it can be concluded that companies manage the relationship between the company and the customer through effective customer relationship management and boost the relationship between them. Therefore, businesses may anticipate the consumers to continue doing business with the product, which can become in effect to build consumer loyalty. Building a superior value for their customers is the key strategy of any firm (Soman, 2010). Previous research indicated that effective communications capability helps businesses build better value for consumers. As the study of Torilo et al. (2017) argued, organizations are still searching for opportunities to build a sustainable strategic edge by providing outstanding service to their various consumer groups. It was also found that companies with higher customer value win the competition and are in the first choice for the customers (Yacob et al., 2016). Through making an income, increasing formation of the company, therefore, creates superior benefit for the consumer (Kotler \& Keller, 2016). The broadband internet service providers will also be willing to offer competitive internet coverage and, in effect, would draw more subscribers with the outstanding consumer experience.

" $\mathrm{H}_{3}$ : Delivering superior value can create loyal customers and have a positive effect on the intention to purchase broadband."

However, with broadband technology developed widely, we could anticipate countries with different communities reaching various levels of ICT development criteria, but not enough research has been conducted into the way broadband providers are developing loyal customers. The availability, use of broadband are directly linked to economic and socio-cultural conditions but it is therefore important to research the significance of valued customers, as such, customers will benefit the ICT sector or the broadband communications industry to a greater degree (Horrigan \& Duggan, 2015).

\section{Conceptual Framework}

To become a satisfied customer or broadband user, customers always look for the speed of broadband, which includes the speed of uploading or downloading the contents and data files.

Copyright (C) 2020, Journal of Advanced Research in Economics and Administrative Sciences (JAREAS), Under a 
Besides, the page load with a stable speed for video streaming sites should have a constant and stable speed. Furthermore, broadband users look for a higher level of technical support, including application service, website design and web hosting services and features. However, certain obstacles can prevent users from purchasing or continuing to use broadband services. If the installation is too difficult and users do not have any knowledge of broadband connectivity or how it works, and if there are no promotional activities for broadband service providers, it is very hard for people to access the broadband internet.

A lack of promotional work and technical customer services can encourage customers to promote negative word of mouth for future users. We know that cost is an important factor that can lead customers to change the current service provider or not even think about using the broadband internet from them any longer. However, if there are alternative service providers they could act as a barrier for the users as well. Since the users could find that changing their current internet providers will be a problem because they are not sure of the speed quality of the new services. Now if we think of the student groups, because of their socio-economic conditions, they might find it difficult to overcome these types of obstacles. When users get assurance and get the core basic services along with affordable cost and quality customer service, it will surely help the broadband internet providers create valued customers. These valued customers may be the existing ones or the prospective ones who will, in turn, have a positive intention to continue the purchases of broadband. The following figure (Fig-1) illustrates the idea.

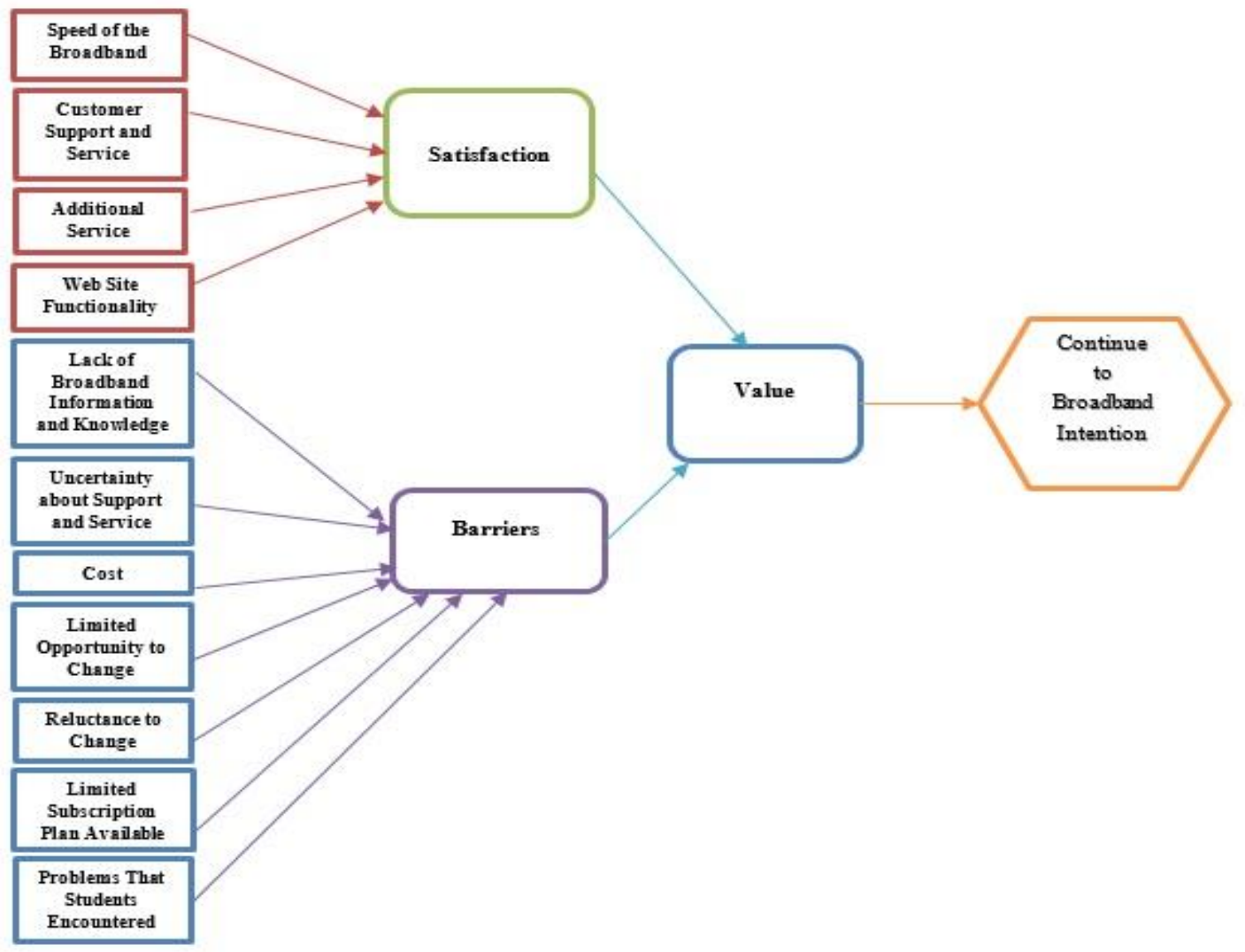

Figure 1: Conceptual Framework, Adapted from (Bhattacharjee et al., 2018) 


\section{Methodology and Procedures}

\section{Sampling Technique}

In this research, purposive sampling was employed to accommodate the inclusion of social media users who had access to online platforms. The advantage of using purposive nonprobability is that this sampling helps to answer specific research questions concerning a particular part of a population characteristic (Neuman, 2014). The sample was chosen from the universities situated in Dhaka city.

\section{Data Collection Procedure}

A close-ended questionnaire with items borrowed from previously developed items on the selected constructs was used to collect data for this research. Online surveys developed using 'Google Forms' was administered through social networking sites (Facebook, Twitter and WhatsApp). The researchers for data redundancy manually screened automatically collected data. The questionnaire was administered for two months (January and February 2020).

Accordingly, 376 responses were obtained from the respondents of the study. This target was set according to the rules of structural equation modeling (SEM) as between 100 and 150 samples. Additionally, (Wijanto, 2008) states that the ideal sample size is five times higher than the number of indicators. The number of indicators in the study questionnaire was 17 , so the ideal sample size was 105 or more. Hence, a sample size of 233 respondents was sufficient to continue the data processing stage.

4. Results and Discussion

Table 1: Specification of the Variables

\begin{tabular}{|c|c|c|}
\hline \multirow{6}{*}{$\begin{array}{l}\text { Speed of the } \\
\text { Broadband }\end{array}$} & SB_1 & Speed of Uploading File \\
\hline & SB_2 & Speed of Downloading File \\
\hline & SB_3 & Speed of Loading Web Pages \\
\hline & SB_4 & Connection with Stable Speed At Anytime \\
\hline & SB_5 & Speed of FTP Sarver \\
\hline & SB_6 & Speed of Video Streaming Site (e.g. YouTube) \\
\hline \multirow{2}{*}{$\begin{array}{l}\text { Customer } \\
\text { Support and } \\
\text { Service }\end{array}$} & CSS_1 & Customer Service \\
\hline & CSS_2 & Technical Support \\
\hline \multirow[t]{5}{*}{ Value } & V_1 & Price/Charge/Cost \\
\hline & V_2 & Assurance of Respecting Customer Privacy (E.G. Not \\
\hline & & $\begin{array}{l}\text { Disclosing Email Address to Third Party Without } \\
\text { Permission) }\end{array}$ \\
\hline & V_3 & $\begin{array}{l}\text { Provide Full Range of Basic Services in Addition to A } \\
\text { Pure }\end{array}$ \\
\hline & & Connection (E.G. Email Accounts and Customer Support) \\
\hline \multirow[t]{2}{*}{$\begin{array}{l}\text { Additional } \\
\text { Service }\end{array}$} & $\mathrm{AS} \_1$ & $\begin{array}{l}\text { Provide A Censorship Facility (E.G. Block Users From } \\
\text { Accessing Specified Sites) }\end{array}$ \\
\hline & AS_2 & Provision of Additional Services Such as Application \\
\hline
\end{tabular}


Service,

Web Site Design Service and Web Hosting

Web Site $\quad$ WSF_1 $\quad$ Sufficient Web Site Content/Functionalities

Functionality

\begin{tabular}{|c|c|c|}
\hline \multirow{6}{*}{$\begin{array}{l}\text { Lack of } \\
\text { Broadband } \\
\text { Information and } \\
\text { Knowledge }\end{array}$} & LBIK_1 & Installation Process Is Complicated \\
\hline & LBIK_2 & Never Use It Before \\
\hline & LBIK_3 & $\begin{array}{l}\text { Do Not See Much Difference Compared to Dial-Up } \\
\text { Service }\end{array}$ \\
\hline & LBIK_4 & $\begin{array}{l}\text { Have Not Heard About Broadband/High-Speed Internet } \\
\text { Connection }\end{array}$ \\
\hline & LBIK_5 & $\begin{array}{l}\text { Do Not Know How Broadband/High-Speed Internet } \\
\text { Connection Works }\end{array}$ \\
\hline & LBIK_6 & Lack of Promotional Activities \\
\hline \multirow{4}{*}{$\begin{array}{l}\text { Uncertainty } \\
\text { about Support } \\
\text { and Service }\end{array}$} & USS_1 & Friends Say That It Is Not Good \\
\hline & USS_2 & Doubt About the Provision of Technical Support \\
\hline & USS_3 & Doubt About the Provision of Customer Service \\
\hline & USS_4 & $\begin{array}{l}\text { Doubt About the Potential Security Risk of } \\
\text { Broadband/High-Speed Connection }\end{array}$ \\
\hline \multirow[t]{3}{*}{ Cost } & C_1 & Hardware Cost Is Expensive \\
\hline & C_2 & Initial Set-Up Cost Is Expensive \\
\hline & C_3 & Ongoing Subscription Cost Is Expensive \\
\hline
\end{tabular}

Limited LOC_1 Do Not See Much Content (E.G. Free Videos) Out on The

Opportunity to Web Which Allow Me to Utilize the Potential Speed of

Change Broadband

LOC_2 Broadband/High-Speed Internet Connection Is Not Available at My Location

\begin{tabular}{lll} 
Reluctance to & RC_1 & It Is A Hassle to Change the Connection \\
\cline { 2 - 3 } Change & $\mathrm{RC} \_2$ & It Is A Hassle to Change Web Hosting Address
\end{tabular}

Limited LSPA_1 Doubt about the stability of speed (always fast or just

Subscription sometimes)

Plan Available $\quad$ LSPA_2 Limited choice of broadband/high-speed subscription plan

Problems That PSE_1 Difficulty in Finding Relevant Information

Students Is $\quad$ PSE_2 $\quad$ Overload of Information

Encountered $\quad$ PSE_3 Takes Long to View Information

Broadband $\quad$ CBI_2 Rate your Overall Uses Barrier on Broadband Uses

Intention

Source: Authors

Copyright (C) 2020, Journal of Advanced Research in Economics and Administrative Sciences (JAREAS), Under a 


\section{Multivariate Normality}

The data should have multivariate normality as a requirement to use SEM-PLS as it is a nonparametric analysis tool (Hair et al., 2019). The test results confirmed that the data set is not as normal as Mardia's multivariate coefficient $\mathrm{p}$-value of less than 0.05 .

\section{Data Analysis Method}

Due to the non-normal nature of the data, this study tested the research model using partial least squares structural equation modeling (PLS-SEM, 3.1). PLS-SEM is a multivariate analysis tool that evaluates path models that have latent constructs (Hair et al., 2011). Model estimation was performed with $\mathrm{r}^{2}, \mathrm{Q}^{2}$, and the effect size $\mathrm{f}^{2}$ that describes the path effect from exogenous construct to endogenous construct (Hair et al., 2019).

The collected data were first analyzed on the measurement model using Smart PLS as this was the crucial measures for evaluating data reliability. As illustrated in Figure 1, the latent constructs that formed the second-order construct (Barrier) were measured. At the same time, the second-order construct for Satisfactions was formatted. It is called a second-order construct because it contains all indicators of its first-order sub-constructs, and later, prediction of the model was made based on the second-order construct Lowry and Gaskin.

\section{Demographic Profile}

Out of the 376 respondents, $60.4 \%$ of the respondents were male, and $39.6 \%$ were female. A large portion of the respondent's age was within the range of 19-24 (92.8\%), which highlights the fact that majority of the respondents were young Bangladeshi students. In terms of the level of study, the majority of the respondents $(39.4 \%)$ were studying in the fourth year of their respective courses.

Table 2: Demographic Profile of the Respondents

\begin{tabular}{|c|c|c|}
\hline Characteristics & Frequency & Percentage \\
\hline \multicolumn{3}{|l|}{ Age } \\
\hline Below 18 & 3 & .8 \\
\hline $19-24$ & 349 & 92.8 \\
\hline $25-30$ & 24 & 6.4 \\
\hline \multicolumn{3}{|l|}{ Gender } \\
\hline Male & 227 & 60.4 \\
\hline Female & 149 & 39.6 \\
\hline \multicolumn{3}{|l|}{ Level of Study } \\
\hline First & 56 & 14.9 \\
\hline Second & 72 & 19.1 \\
\hline Third & 99 & 26.3 \\
\hline Fourth & 148 & 39.4 \\
\hline Masters/PhD & 1 & .3 \\
\hline
\end{tabular}

Source: Authors 


\section{Reliability and Validity}

The mentioned test demonstrated relationships between barriers, satisfaction and the continuous broadband intention of customers. As shown in Table 3, all values of Cronbach's alpha, composite reliability, and rho-A are well above the threshold of 0.70 (Hair et al., 2019). These results signified that the constructs were reliable and performed well. AVE for each construct was above 0.50 , indicated the convergent validity (Hair et al., 2011). Finally, all the VIF values were less than 3 , establishing the lack of multi-collegiality issues among the study constructs.

\section{Reliability Analysis}

Table 3: Reliability test

\begin{tabular}{lccccc}
\hline Variable & $\begin{array}{c}\text { Cronbach's } \\
\text { Alpha }\end{array}$ & rho_A & $\begin{array}{c}\text { Composite } \\
\text { Reliability }\end{array}$ & $\begin{array}{c}\text { Average Variance } \\
\text { Extracted (AVE) }\end{array}$ & $\begin{array}{c}\text { Variance } \\
\text { Inflation } \\
\text { Factor }\end{array}$ \\
\hline $\boldsymbol{A S}$ & 0.730 & 0.733 & 0.844 & 0.730 & 1.486 \\
Barriers & 0.864 & 0.870 & 0.885 & 0.756 & 1.200 \\
$\boldsymbol{C S S}$ & 0.774 & 0.777 & 0.898 & 0.815 & 1.449 \\
Cost & 0.748 & 0.753 & 0.857 & 0.667 & 1.467 \\
LBIK & 0.767 & 0.758 & 0.783 & 0.676 & 1.617 \\
$\boldsymbol{L O C}$ & 0.794 & 0.786 & 0.798 & 0.664 & 1.395 \\
$\boldsymbol{L S P A}$ & 0.895 & 0.797 & 0.706 & 0.567 & 1.271 \\
$\boldsymbol{P S E}$ & 0.783 & 0.775 & 0.809 & 0.515 & 1.578 \\
$\boldsymbol{R C}$ & 0.792 & 0.792 & 0.906 & 0.828 & 1.318 \\
$\boldsymbol{S B}$ & 0.717 & 0.734 & 0.810 & 0.620 & 1.371 \\
Satisfaction & 0.811 & 0.821 & 0.854 & 0.651 & 1.200 \\
$\boldsymbol{U S S}$ & 0.891 & 0.865 & 0.767 & 0.656 & 1.633 \\
Value & 0.726 & 0.708 & 0.795 & 0.563 & 1.000 \\
$\boldsymbol{W S F}$ & 1.000 & 1.000 & 1.000 & 1.000 & 1.312 \\
$\boldsymbol{C B I}$ & 0.764 & 0.825 & 0.800 & 0.672 & - \\
\hline \multicolumn{2}{c}{ Source: Authors } & & & &
\end{tabular}

Fornell-Larcker criterion value for each contract was less than 0.70 to establish discriminant validity for each construct (Hair et al., 2019). HTMT ratio essentially was less than 0.90 to provide the evidence for discriminant validity for study construct (Fassott et al., 2016). The table below shows that the study had evidence of discriminant validity.

Table 4: Correlation Matrix

\begin{tabular}{|c|c|c|c|c|c|c|c|c|c|c|c|c|c|c|c|}
\hline \multicolumn{16}{|c|}{ Fronell-Larcker Criterion } \\
\hline & AS & $\begin{array}{c}\text { Barri } \\
\text { ers }\end{array}$ & CBI & CSS & Cost & $\begin{array}{c}\text { LBI } \\
\mathrm{K}\end{array}$ & LOC & $\begin{array}{c}\text { LSP } \\
\text { A }\end{array}$ & PSE & $\mathrm{RC}$ & SB & $\begin{array}{l}\text { Satisfa } \\
\text { ction }\end{array}$ & USS & $\begin{array}{c}\text { Valu } \\
\mathrm{e}\end{array}$ & WSF \\
\hline AS & 0.654 & & & & & & & & & & & & & & \\
\hline $\begin{array}{l}\text { Barrie } \\
\text { rs }\end{array}$ & 0.368 & 0.506 & & & & & & & & & & & & & \\
\hline CBI & 0.687 & 0.673 & 0.620 & & & & & & & & & & & & \\
\hline CSS & 0.486 & 0.319 & 0.687 & 0.603 & & & & & & & & & & & \\
\hline Cost & 0.234 & 0.710 & 0.432 & 0.163 & 0.517 & & & & & & & & & & \\
\hline LBIK & 0.291 & 0.584 & 0.566 & 0.264 & 0.430 & 0.613 & & & & & & & & & \\
\hline LOC & 0.224 & 0.608 & 0.408 & 0.159 & 0.345 & 0.412 & 0.615 & & & & & & & & \\
\hline LSPA & 0.258 & 0.511 & 0.386 & 0.152 & 0.269 & 0.296 & 0.306 & 0.753 & & & & & & & \\
\hline PSE & 0.259 & 0.445 & 0.475 & 0.247 & 0.452 & 0.455 & 0.316 & 0.363 & 0.717 & & & & & & \\
\hline
\end{tabular}




\begin{tabular}{|c|c|c|c|c|c|c|c|c|c|c|c|c|c|c|c|}
\hline $\mathrm{RC}$ & 0.258 & 0.596 & 0.432 & 0.277 & 0.370 & 0.344 & 0.311 & 0.338 & 0.338 & 0.910 & & & & & \\
\hline SB & 0.405 & 0.307 & 0.816 & 0.427 & 0.180 & 0.306 & 0.181 & 0.180 & 0.202 & 0.178 & 0.648 & & & & \\
\hline $\begin{array}{l}\text { Satisfa } \\
\text { ction }\end{array}$ & 0.612 & 0.408 & 0.544 & 0.745 & 0.238 & 0.367 & 0.241 & 0.242 & 0.279 & 0.283 & 0.861 & 0.592 & & & \\
\hline USS & 0.254 & 0.538 & 0.479 & 0.231 & 0.395 & 0.510 & 0.443 & 0.298 & 0.470 & 0.312 & 0.205 & 0.276 & 0.676 & & \\
\hline Value & 0.443 & 0.292 & 0.622 & 0.538 & 0.166 & 0.307 & 0.169 & 0.132 & 0.177 & 0.217 & 0.540 & 0.654 & 0.174 & 0.750 & \\
\hline WSF & 0.412 & 0.237 & 0.553 & 0.348 & 0.153 & 0.224 & 0.190 & 0.156 & 0.122 & 0.169 & 0.384 & 0.590 & 0.136 & 0.398 & 0.365 \\
\hline \multicolumn{16}{|c|}{ Heterotrait-Monotrait Ratios } \\
\hline AS & 0.505 & & & & & & & & & & & & & & \\
\hline $\begin{array}{l}\text { Barrie } \\
\text { rs }\end{array}$ & 0.867 & 0.697 & & & & & & & & & & & & & \\
\hline CBI & 0.698 & 0.389 & 0.932 & & & & & & & & & & & & \\
\hline CSS & 0.342 & 0.862 & 0.850 & 0.218 & & & & & & & & & & & \\
\hline Cost & 0.456 & 0.833 & 0.768 & 0.370 & 0.605 & & & & & & & & & & \\
\hline LBIK & 0.402 & 0.865 & 0.770 & 0.260 & 0.569 & 0.720 & & & & & & & & & \\
\hline LOC & 0.559 & 0.880 & 0.686 & 0.260 & 0.513 & 0.541 & 0.774 & & & & & & & & \\
\hline LSPA & 0.399 & 0.758 & 0.763 & 0.343 & 0.630 & 0.668 & 0.541 & 0.692 & & & & & & & \\
\hline PSE & 0.367 & 0.713 & 0.779 & 0.357 & 0.479 & 0.468 & 0.495 & 0.705 & 0.460 & & & & & & \\
\hline $\mathrm{RC}$ & 0.597 & 0.392 & 0.814 & 0.571 & 0.245 & 0.438 & 0.327 & 0.342 & 0.289 & 0.232 & & & & & \\
\hline SB & 0.883 & 0.487 & 0.738 & 0.902 & 0.307 & 0.500 & 0.394 & 0.436 & 0.373 & 0.345 & 0.861 & & & & \\
\hline $\begin{array}{l}\text { Satisfa } \\
\text { ction }\end{array}$ & 0.416 & 0.742 & 0.640 & 0.334 & 0.602 & 0.812 & 0.835 & 0.633 & 0.738 & 0.454 & 0.314 & 0.394 & & & \\
\hline USS & 0.702 & 0.397 & 0.636 & 0.766 & 0.248 & 0.471 & 0.303 & 0.259 & 0.278 & 0.313 & 0.795 & 0.704 & 0.284 & & \\
\hline Value & 0.518 & 0.258 & 0.654 & 0.395 & 0.178 & 0.279 & 0.272 & 0.256 & 0.147 & 0.190 & 0.453 & 0.653 & 0.180 & 0.506 & \\
\hline WSF & 0.518 & 0.258 & 0.654 & 0.395 & 0.178 & 0.279 & 0.272 & 0.256 & 0.147 & 0.190 & 0.453 & 0.653 & 0.180 & 0.506 & \\
\hline
\end{tabular}

Source: Authors

\section{Path Analysis}

The $r^{2}$ value for the input variables on the CBI explained that average $62.3 \%$ of change in CBI could be explained by value. The predictive relevance $\left(\mathrm{Q}^{2}\right)$ value for the part of the model was the average 0.262 indicating a medium predictive relevance (Fassott et al., 2016).

\section{Hypothesis testing}

Table 5: Hypothesis Testing

\begin{tabular}{llccccccc}
\hline & Hypothesis & Coefficient & t-values & Sig. & Decision & $\boldsymbol{Q}^{2}$ & $\boldsymbol{r}^{\mathbf{2}}$ & $\boldsymbol{f}^{\mathbf{2}}$ \\
\hline 1 & Barrier $\rightarrow$ Value & 0.030 & 0.764 & 0.000 & Reject & 0.235 & - & 0.625 \\
\hline 2 & Satisfaction $\rightarrow$ Value & 0.642 & 17.327 & 0.000 & Accept & 0.327 & 0.428 & 0.601 \\
\hline 3 & Value $\rightarrow$ CBI & 0.622 & 21.195 & 0.000 & Accept & 0.224 & 0.387 & 0.631 \\
\hline & $\quad$ Source: Authors & & & & & & &
\end{tabular}

Table 5 shows path coefficient, t-values, and significance level and the results revealed that Flow ( $\beta=0.030, p=0.502$ ) has a significant and positive effect of the Barrier on the Value and it was statistically insignificant, i.e. our hypothesis was rejected. As for the factor affecting Value, the findings presented in the above table showed that effect of Satisfaction on Value $(\beta=0.624, p=$ 0.000 ) is positive and statistically significant. Finally, the path coefficient for the Value on CBI $(\beta=0.622, p=0.000)$, depicted the effect of Value on CBI as significant and positive as well.

In this research paper, it was also found out that the Barrier of the internet uses created less positive value but it was not statistically significant. The hypothesis is thereby rejected. Therefore, there was no positive impact of the barrier on value. On the other hand, the customer or user satisfaction created a huge positive impact on value creation and statistically significant 
and supported our hypothesis. Finally, it can be said that the value increased Continue to Broadband Intention and it was statistically significant and supported our hypothesis.

\subsection{Mediating Effects}

As noted in the below table, the mediation effect of Value between the Barrier and CBI revealed that Value mediated the relationship between Barrier and CBI $(\beta=0.019, p=0.002)$. The relationship between Satisfaction and CBI was mediated by the Value. The result also depicted that value mediates the relationship between satisfaction and CBI $(\beta=0.399, p=0.000)$. Mediator "Value" indicated the causal relationship between Barrier and satisfaction, which lead to continuous Broadband intention.

Table 06: Meditating Effect

\begin{tabular}{lllll}
\hline & B & t-value & Sig. & Decision \\
\hline HM1: Barrier $\rightarrow$ Value $\rightarrow$ CBI & 0.019 & 0.758 & 0.002 & Mediation \\
HM2: Satisfaction $\rightarrow$ Value $\rightarrow$ CBI & 0.399 & 10.096 & 0.000 & Mediation \\
\hline
\end{tabular}

Source: Authors

\section{Discussion}

The purpose of this research was to measure broadband use among young and adolescents and the factors associated with intensive internet use. We conducted a cross-sectional survey study with young and adolescent participants from the universities at Dhaka city between January to February 2020. Gender was an important concern of this study and both males and females were chosen as a research sample, as the previous study depicted that there was gender disparity prevailed in the adoption and usage of information and communications technologies (ICTs) (Dholakia et al., 2004).The majority of the respondents were young and studying at the different educational levels in Bangladesh. The socio-economic condition of the respondents was also an important concern in this study. Diversity of the respondents had a great emphasis on other previous studies (Sánchez-Martínez, and Otero, 2009), as it helped to synthesize hypothesis and to generalize the findings. The online platform was used for the data collection of this study.

Though some literature considers this technique as a limitation, in the age of advancement of ICT, these methods have now been highly appreciated (Van Selm and Jankowski, 2006) and well accepted by the researchers (Fassott et al., 2016). However, this study dealt with different factors related to the uses of broadband for young and adolescents. Besides, these were speed of the broadband, customer support and service, lack of broadband internet-related information and facts, uncertainty about customer support and service, cost of broadband, fewer opportunities to change the service provider and so on. For instance, Mirza and Beltrán(2013) in their study in New Zealand found barriers and declining factors of broadband uses, which was similar to this study. However, this study found that participants, despite having the barriers, were reasonably satisfied at different levels and it was a major motivation in the use of broadband. The findings of this study echoed with the study findings of the Pew Research Center's Internet \& American Life Project that marked that in-home high-speed broadband adoption rates increased (Horrigan and Smith, 2008). 
This study had certain limitations, for example among students of university level, in which most people have basic or moderate IT skills. The report indicated that large bands sustain a fair standard of customer support at least, and students as survey respondents came from a socioeconomic context that was almost identical, where cost and value were quite relevant facts to take into account. Since consumers or more specifically students who searched for cost drivers and other demand indicators, broadband companies should analyze these variables closely to get more loyal customers. If broadband service providers could give their area based innovative custom-tailored offerings, massive user groups could carry them to the next stage. Also, further research is needed to detect demand for broadband in rural areas of the country, including those with low IT knowledge and low economic background.

\section{Conclusion and Suggestion}

This research explored the prevalence and trends of broadband usage primarily among the young and adolescent in Bangladesh as members of a particular age group in the Bangladeshi population. It revealed that most of the respondents used the internet for one to five hours a day routinely with the hope of quality coverage beyond their affordability to connect, access, and entertain. The aim was to determine whether the use of broadband was dissatisfied or impeded. The study revealed that the degree of total frustration is below ten per cent, even though the severe challenge is considered very small. The study also showed that most of the participants were reasonably satisfied at different levels and it was a major motivation in the use of broadband. It is therefore suggested that service providers should consider upgrading internet speed cautiously because demand is still growing.

\section{Author Contributions}

All authors have contributed equally and they read and approved the final manuscript.

\section{Data sharing}

The datasets analyzed during this study are available from the authors on reasonable request.

\section{Conflict of Interest}

The authors of the article declare no conflict of interest.

\section{Funding}

This research study was not funded by any institution.

\section{References}

Adams, P., Farrell, M., Dalgarno, B., \& Oczkowski, E. (2017). Household adoption of technology: The case of high-speed broadband adoption in Australia. Technology in Society, 49, 37-47. https://doi.org/10.1016/j.techsoc.2017.03.001 
Alderete, M. V. (2019). Broadband adoption in Latin American countries: does geographic proximity matter?. Revista Problemas del Desarrollo, 198, 50. https://doi.org/10.22201/iiec.20078951e.2019.198.67411

Assaf, M., Naumann, D. A., Signoles, J., Totel, É., \& Tronel, F. (2017). Hypercollecting semantics and its application to static analysis of information flow. ACM SIGPLAN Notices, 52(1), 874-887.https://doi.org/10.1145/3093333.3009889

Bashir, M., \& Verma, R. (2017). Value creation through business model innovation: a case study of connect broadband. Prabandhan: Indian Journal of Management, 10(3), 5360.https://doi.org/10.17010/PIJOM\%2F2017\%2FV10I3\%2F111426

Bhattacharjee, A., Rashedhasanpolas, M., \& Moin, M. (2018). The Effects of Broadband Service Quality on User's Value and Loyalty: A Study on Foreign Customers In Malaysia. IOSR Journal of Business and Management, 20(2), 48-58.https://doi.org/ 10.9790/487X2002024858

Birba, O., \& Diagne, A. (2012). Determinants of adoption of Internet in Africa: Case of 17 subSaharan countries. Structural Change and Economic Dynamics, 23(4), 463 472.https://doi.org/10.1016/j.strueco.2012.06.003

Buttle, F., \& Maklan, S. (2019). Customer relationship management: concepts and technologies. Chin, W. W. (2010). How to write up and report PLS analyses. In Handbook of partial least squares (pp. 655-690). Springer, Berlin, Heidelberg.https://doi.org/10.1007/978-3540-32827-8_29

Cedergren, M. (2003). Open content and value creation. https://doi.org/10.5210/fm.v8i8.1071

Choudrie, J., \& Dwivedi, Y. K. (2004). Analyzing the Factors of Broadband Adoption in the Household. ECIS 2004 Proceedings, 42.https://doi.org/10.4018-978-1-59904-783-6

Copps, M. J. (2009). Bringing broadband to rural america: Report on a rural broadband strategy. Federal Communications Commission. https://doi.org/10.1007/s11149-0109119-y.

Dholakia, R. R., Dholakia, N., \& Kshetri, N. (2004). Gender and Internet usage. The internet encyclopedia.https://doi.org/10.1002/047148296X.tie070

Doster, L. (2013). Fear of missing out: Is voyeurism the real motive behind teen consumption of social media?. ACR European Advances.

Dwivedi, Y. K., \& Lal, B. (2007). Socio-economic determinants of broadband adoption. Industrial Management \& Data Systems.https://doi.org/ 10.1108/02635570710750417

Dwivedi, Y. K., Khoumbati, K., \& Lal, B. (2007). Factors affecting consumers' behavioural intention to adopt broadband in Pakistan. Transforming Government: People, Process and Policy.https://doi.org/10.1108/17506160710778112

Fassott, G., Henseler, J., \& Coelho, PS (2016). Testing moderating effects in PLS path models with composite variables. Industrial Management \& Data Systems.https://doi.org/10.1108/IMDS-06-2016-0248

Gaggioli, A., Pioggia, G., Tartarisco, G., Baldus, G., Corda, D., Cipresso, P., \& Riva, G. (2013). A mobile data collection platform for mental health research. Personal and Ubiquitous Computing, 17(2), 241-251.https://doi.org/10.1007/s00779-011-0465-2 
Gefen, D., \& Straub, D.W. (2004). Consumer trust in B2C e-commerce and the importance of social presence: Experiments in e-products and e-services. Omega, 32(6), 407- 424. https://doi:10.1016/j.omega.2004.01.006

Grubesic, T. H. (2010). Efficiency in broadband service provision: A spatial analysis. TelecommunicationsPolicy, 34(3), 117-131.https://doi.org/10.1016/j.telpol.2009.11.017

Hair, J. F., Risher, J. J., Sarstedt, M., \& Ringle, C. M. (2019). When to use and how to report the results of PLS-SEM. European Business Review.https://doi.org/10.1108/ebr-11-20180203

Hair, J. F., Ringle, C. M., \& Sarstedt, M. (2011). PLS-SEM: Indeed a silver bullet. Journal of Marketing theory and Practice, 19(2), 139-152.https://doi.org/10.2753/MTP10696679190202

Horrigan, J. B., \& Smith, A. (2008). Home broadband adoption 2008. Washington, DC: Pew Internet \&American Life Project.

Horrigan, J. B. (2010). Broadband adoption and use in America. Washington, DC: Federal Communications Commission.

Horrigan, J. B., \& Duggan, M. (2015). Home broadband 2015. Pew Research Center, 21. Hossain, A. (2004). Access to Internet: Bangladesh Perspective. In Ministry of Science and Information \& Communication Technology, Government of People's Republic of Bangladesh, Global Indicators Workshop on Community Access to ICTs, Retrieved August (Vol. 17, p. 2008).

Islam, T., Rahman, S., \& Nahar, N. (2015). Factors affecting customer satisfaction in 3G service. American Scientific Research Journal for Engineering, Technology, and Sciences (ASRJETS), 14(3), 202-217.

Kotler, P., Keller, K. L., Brady, M., Goodman, M., \& Hansen, T. (2019). Marketing management. Pearson UK.

Kotler, P., \& Keller, K. L. (2016). Marketing management (15th ed.). England: Pearson EducationalLimited

Koutroumpis, P. (2019). The economic impact of broadband: Evidence from OECD countries. Technological Forecasting and Social Change, 148, 119719.https://doi.org/10.1016/j.techfore.2019.119719

Marino, M. S. (2017). The Problems of the First Mover: The Case of British Telecom. In The Privatisation of European Telecommunications (pp. 113-127).

Routledge.https://doi.org/10.4324/9781351145602-7

Meyoki, N. L., \& Kavindah, L. (2019). Exploration of Adoption of Information Communication Technology by Tourist Camps in Maasai Mara, Narok County, Kenya. International Journal of Current Aspects, 3(VI), 291-308.https://doi.org/10.35942/ijcab.v3ivi.90

Mirza, F., \& Beltrán, F. (2013). Drivers and Barriers to the Uptake of a FTTH Ultra-Fast Broadband in New Zealand.https://doi.org/10.2139/ssrn.2241514

Momotaz, S. N. (2019). Effects of Service Quality and Perceived Value on Customer Satisfaction to Mobile Internet Service: Evidence from Bangladesh. International Review of Business Research Papers, 15(1).

Neuman, W. L. (2014). Basics of social research. Pearson/Allyn and Bacon. 
Owens, I., Wilson, T., \& Abell, A. (2019). Information and Business Performance:astudy of information

systems and services in high-performing companies. Walter de Gruyter $\mathrm{GmbH} \& \mathrm{Co}$ KG.https://doi.org/10.1515/9783110977660

Rappoport, P. N., Kridel, D. J., \& Taylor, L. D. (2002). The demand for broadband: access, content, and the value of time. Broadband: Should we regulate high-speed Internet access, 57-82.https://doi.org/10.1007/978-1-4615-0861-8_3

Sánchez-Martínez, M., \& Otero, A. (2009). Factors associated with cell phone use in adolescents in the community of Madrid (Spain). CyberPsychology \& Behavior, 12(2), 131137.https://doi.org/10.1089/cpb.2008.0164

Sianipar, E., Sucherly, H., Kaltum, U., \& Oesman, Y. M. (2018). Customer Relationship Management to

Customer Value \& Customer Loyalty of Fixed Broadband: Study Case on Fixed Broadband Company in Indonesia. Management, 6(6), 444-453. https://doi.org/10.17265/2328-2185/2018.06.003

Seuwou, P., Banissi, E., \& Ubakanma, G. (2017, January). User acceptance of information technology: A

critical review of technology acceptance models and the decision to invest in Information Security. In International Conference on Global Security, Safety, and Sustainability (pp. 230-251). Springer, Cham.https://doi.org/10.1007/978-3-319-51064-4_19

Soman, D. n-Marandi, S. 2010. Managing Customer Value. One Stage At ATime.Singapore. https://doi.org/10.1142/9789812838285_0001

Stanton, N. A., Hedge, A., Brookhuis, K., Salas, E., \& Hendrick, H. W. (Eds.). (2004). Handbook of human factors and ergonomics methods. CRC press.https://doi.org/10.1201/9780203489925

Strover, S. (2018). Reaching rural America with broadband internet service. The Conversation. http://theconversation. com/reaching-rural-america-with-broadbandinternetservice82488.

Touray, A., Salminen, A., \& Mursu, A. (2015). Internet adoption at the user level: empirical evidence from the Gambia. Information Technology for Development, 21(2), 281296.https://doi.org/10.1080/02681102.2013.874319

Townsend, L., Sathiaseelan, A., Fairhurst, G., \& Wallace, C. (2013). Enhanced broadband access as a solution to the social and economic problems of the rural digital divide. Local Economy, 28(6), 580-595.https://doi.org/10.1177\%2F0269094213496974

Troilo, G., De Luca, L. M., \& Guenzi, P. (2017). Linking data-rich environments with service innovation

in incumbent firms: A conceptual framework and research propositions. Journal of Product Innovation Management, 34(5), 617-639.https://doi.org/10.1111/jpim.12395

Van Selm, M., \& Jankowski, N. W. (2006). Conducting online surveys. Quality and quantity, 40(3), 435-456.https://doi.org/10.1007/s11135-005-8081-8 
Venkatesh, V., Davis, F., \& Morris, M. G. (2007). Dead or alive? The development, trajectory and future of technology adoption research. Journal of the association for information systems, $8(4), 1$.

https://doi.org/10.17705/1jais.00120

Venkatesh, V., Thong, J. Y., \& Xu, X. (2012). Consumer acceptance and use of information technology:

extending the unified theory of acceptance and use of technology. MIS quarterly, 157178.https://doi.org/10.2307/41410412

Wijanto, S. H. (2008). Structural equation modeling dengan Lisrel 8.8. Yogyakarta: Graha Ilmu.

Yacob, S., Sucherly, D. S., \& Mulyana, A. (2016). Do Really Competitive Strategy and Strategic Alliances Effect nn Retail Business Performance. International Journal of Economics, Management and Commerce, 4(2), 783-796.

Zickuhr, K., \& Madden, M. (2012). Older adults and internet use. Pew Internet \& American Life Project, 6. 